\title{
A SYNOPSIS OF THE GENUS SCIRPUS sens. lat. (CYPERACEAE) IN AUSTRALIA
}

\author{
K. L. WILSON \\ (Accepted for publication 27.11.1980)
}

\begin{abstract}
Wilson, K. L. (National Herbarium of New South Wales, Royal Botanic Gardens, Sydney, New South Wales, Australia) 1981. The genus Scirpus sens. lat. (Cyperaceae) in Australia. Telopea 2(2): 153-172.-All Australian species (both native and naturalized) that were formerly referred to Scirpus sens. lat. are placed in the segregate genera Bolboschoenus (3 spp.), Hymenochaeta (1 sp.), Isolcpis (28 spp.), Schoenoplectus (11 spp.), Scirpus sens. strict. (1 sp.), or are referred to other genera (Cyperus sens. lat., C. hamulosus: and Lipocarpha, L. microcephala). New combinations are made for Isolepis humillima, I. montivaga, I. oldfieldiana, I. producta, I. setiformis, I. stellata, I. tasmanica, I. victoriensis and I. wakefieldiana. Keys arc provided to genera and species.
\end{abstract}

\section{INTRODUCTION}

Scirpus has been circumscribed in a broad sense in all Australian and many other Floras, even though it has been regarded as heterogeneous by recent authors (e.g., Kern 1974). Raynal (1973) described Scirpus as "manifestement un genre résidu", composed of all the elements left in the subfamily Cyperoideae after the most strikingly different elements had been separated as genera. This is an apt description.

In this paper, the species of Scirpus sens. lat. occurring in Australia are placed in their segregate genera with appropriate comments on their status, relationships and distribution. Keys are provided to both genera and species. Reference is made to species descriptions in recent Floras (where available), while further generic synonymy and descriptions may be found in Koyama $(1958,1979)$. Comments are made on poorly known species or groups that need further study, as I do not pretend in this paper to solve all the taxonomic problems associated with these taxa.

Scirpus was heterogeneous even when first described, including species now assigned to Cyperus sens. lat., Eleocharis, Fimbristylis and Scleria, as well as species now in segregate genera such as Isolepis. Many new segregate genera were set up in the nineteenth century and concepts became very confused. This led to extensive synonymising of genera, culminating in the revision of Scirpus by Koyama (1958), in which even Eriophorum, Fuirena and Hemicarpha were included in Scirpus. Recent workers, including Koyama himself (1979), have rejected Koyama's inclusive view of Scirpus as leading to a large unwieldy genus that includes various groups not closely related to each other.

Evidence from embryological and physiological studies has given fresh impetus to taxonomic study of the subfamily Cyperoideae, to which Scirpus and most of its segregates belong. In his study of embryo-types in Cyperoideae, Van der Veken (1965) classified the mature embryos into six types (with some variants), all of which he found represented in Scirpus sens. lat. He distinguished these types on the basis of the shape of the mature embryo, the position of the coleoptile and radicle at maturity, and the orientation of the germination pore of the coleoptile ("le pore ou la fente germinative du coléoptile"). The embryos of Australian Scirpus segregates fall into three of his types (see Table 1), and the detailed listing of genera that follows in this paper groups them accordingly. Van der Veken did not make any formal nomenclatural changes but he gave his opinion on the appropriate taxonomic 
treatment for each group of species he studied. His opinion that no genus should have more than one embryo-type represented in it, although several genera could have the same embryo-type, was undoubtedly a major inspiration for the studies of Haines \& Lye and of Raynal (see, for example, Haines \& Lye (1971), Lye (1971 a \& c) and Raynal (1973)).

TABLE 1

Classification of embryo-types of Australian Scirpus segregates

(extracted from Van der Veken (1965))

\begin{tabular}{|c|c|c|c|}
\hline & Fimbristylis-type & $\begin{array}{c}\text { Schoenoplectus-type } \\
\text { ("Scirpus" of Van der Veken) }\end{array}$ & Cyperus-type \\
\hline Shape of embryo & \pm Turbinate & $\begin{array}{l} \pm \text { Mushroom-shaped } \\
\text { ("fongiforme") }\end{array}$ & $\begin{array}{l}\text { Ellipsoid to } \\
\text { narrowly turbinate }\end{array}$ \\
\hline Final position of coleoptile & Basal & Basal & Basal \\
\hline Final position of radicle & Lateral & Lateral & Lateral \\
\hline $\begin{array}{l}\text { Orientation of the germi- } \\
\text { nation pore relative to } \\
\text { the first leaf }\end{array}$ & Perpendicular & Parallel & Parallel \\
\hline Genera in Australia & Scirpus sens. str. & $\begin{array}{l}\text { Hymenochaeta } \\
\text { Bolboschoenus } \\
\text { Schoenoplectus }\end{array}$ & $\begin{array}{l}\text { Isolepis } \\
\text { Lipocarpha } \\
\text { Cyperus sens. lat. }\end{array}$ \\
\hline
\end{tabular}

Another stimulus to the study of generic composition and relationships in the Cyperoideae was the discovery of the "Hatch-Slack" or " $\mathrm{C}_{4}$ " photosynthetic pathway and its anatomical expression ("Kranz" or "chlorocyperoid" anatomy) (Raynal 1972; Brown 1975; Carolin et al. 1977). Most Scirpus segregates have the $\mathrm{C}_{3}$ type of photosynthesis but some small groups have been removed from Scirpus partly on the basis of their $\mathrm{C}_{4}$ photosynthesis, e.g. Rikliella, Nemum and Hemicarpha (Raynal 1973) and Cyperus hamulosus (see p. 171).

Both embryo-types and photosynthesis-types were used by Raynal (1973) to indicate relationships in his diagram of hypothetical phylogenetic relationships in Cyperoideae. This diagram provides a useful summary of generally accepted taxa and relationships although some changes could be made to it. Haines \& Lye and Raynal have done much to remove discordant elements from Scirpus and to clarify nomenclature in their respective series of papers in Botaniska Notiser and Adansonia.

Schuyler (1971 a \& b) examined such characters as epidermal cell details of the achenes, leaf anatomy, and style morphology in several groups of species included in Scirpus sens. lat. He did not follow through his studies and recognize segregate genera, despite finding various correlations amongst the characters examined; rather (Schuyler 1971 b) he urged caution in recognizing genera until "a thorough systematic analysis of microscopic characters" had been carried out. Such a complete analysis has yet to be published, although Oteng-Yeboah (1974 a \& b) made nomenclatural changes in the Scirpus segregates as a result of morphological and anatomical studies in the Cyperoideae. Unfortunately Oteng-Yeboah's published papers are brief and do not represent a complete exposition of his scheme of classification.

Many species in Cyperaceae are hosts to smut and rust fungi and, while some caution is necessary in interpreting the relationships, there are interesting correlations of host and parasite specificity, as pointed out in the review by Savile (1979). Smuts 
are rare on Scirpus sens. lat, but rusts are more common and they have been investigated for various northern hemisphere species by Savile $(1972,1979)$. $\mathrm{He}$ found eleven species of Puccinia and Uromyces, belonging to two evolutionary lineages, on species now assigned to Scirpus sens. str., Bolboschoenus, Eriophorum, Fuirena, Schoenoplectus and Trichophorum. The fungi were all host-limited, either to a single species or several species within one of these segregate genera, except for Puccinia angustata which was found most commonly on Scirpus but also occasionally attacked Eriophorum species. Savile suggested that the latter occurrence could be due to propinquity of the hosts as the two genera are otherwise host to different Puccinia species, both in Europe and North America. As indicated by the title of Savile's review, the occurrence of fungal parasites is no more than an aid to plant classification and there has been by no means a comprehensive survey of Scirpus sens. lat. but the results outlined above are nevertheless in general agreement with proposed classifications in this group.

It is clear from the various studies that have been undertaken that Scirpus sens. lat. is an unnatural genus and should be divided into several genera. Not only does this result in more natural groupings of species but it has the additional benefit, as pointed out by Raynal (1977), of giving a clearer picture of the biogeography of the subfamily Cyperoideae. Thus, amongst the Scirpus segregates, there is a pantropical group (Schoenoplectus and allies) of African origin, a boreal group (Scirpus sens. str. and allies), and a southern hemisphere, Gondwanian group (Isolepis and allies) which is especially well-developed in eastern Africa and Australasia.

Some problems of generic limits remain (for example, in the Ficinia-ScirpoidesIsolepis group) but this is not considered to be an argument, by me or other recent authors such as Raynal (1973), for maintaining such an unwieldy assemblage of species as Scirpus sens. lat. Rather, genera should be separated using all available evidence, with an indication of where problems remain. This is the policy $I$ have followed in placing Australian species in segregate genera. Problems of generic delimitation in the Bolboschoenus-Hymenochaeta-Schoenoplectus and EleogitonFicinia-Isolepis-Scirpoides groups are discussed on pp. 156-157 and pp. 161-162 respectively.

\section{KEY TO SEGREGATE GENERA IN AUSTRALIA}

1. Involucral bracts leafy, usually several; culms nodeless to several-noded; hypogynous bristles present; perennials.

2. Spikelets less than $1 \mathrm{~cm}$ long; inflorescence branches usually scabrous.

3. Culms noded; Fimbristylis-type embryo $\ldots \ldots \ldots \ldots \ldots \ldots \ldots \ldots$. Scirpus

3.* Culms nodeless: Schoenoplectus-type embryo ........... 2. Hymenochaeta

2.* Spikelets 1-4 cm long; inflorescence branches not scabrous; culms noded; Schoenoplectus-type embryo ............................. Bolboschoenus

1.* Involucral bracts culm-like, usually $1(-2)$; culms nodeless (except in aquatic Isolepis spp.); hypogynous bristles absent or present; annuals or perennials.

4. Hypogynous bristles present and/or nuts transversely rugose and/or plants amphicarpous (i.e., basal spikelets present) and/or $t$ stout perennials; Schoenoplectus-type embryo $\ldots \ldots \ldots \ldots \ldots \ldots \ldots \ldots \ldots \ldots \ldots \ldots \ldots, \ldots \ldots$ 4. Schoenoplectus

4.* Hypogynous bristles absent; nuts not rugose; plants not amphicarpous; annuals or slender aquatic perennials ( $I$. nodosa a slender terrestrial perennial but then inflorescence a dense globose head and a disc present at the base of the ovary);

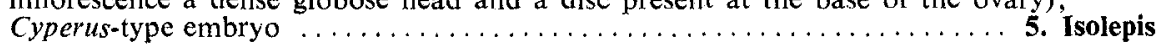


1. SCIRPUS L. sens. str., Sp. Pl. 1: 47 (1753); Gen. Pl., edn 5: 26 (1754); Koyama, J. Fac. Sci. Univ. Tokyo, Sect. 3, Bot., 7: 282, 292 (1958); Oteng-Yeboah, Notes Roy. Bot. Gard. Edinburgh 33: 311 (1974).

Type species: S. sylvaticus L.

About 20 species; mainly boreal, especially well developed in North America and Asia.

There has been disagreement about the typification of this genus but $S$. sylvaticus, the choice of Hitchcock \& Green (1929), is now generally accepted as the lectotype. Most American botanists have taken $S$. lacustris L. as lectotype but that is now accepted as the type of Schoenoplectus (q.v.).

1. S. polystachyus $F$. Muell., Trans. Philos. Soc. Victoria 1: 108 (1855).Lectotype (here designated): Lake Omeo, Mueller 1.1854 (MEL).

Description: Burbidge \& Gray (1970: 80).

Distribution: Tableland regions of southern Qld., N.S.W. and Vic.

This species belongs to Section Lineatus of Oteng-Yeboah (1974 b), characterised by the tufted habit and long, filiform hypogynous bristles.

2. HYMENOCHAETA Beauv. ex Lestib., Essai Fam. Cypéracées: 43 (1819); Nees, Edinburgh New Philos. J. 17 (34): 264 (1834), as "Hymenochaete."-Scirpus sect. Actinoscirpus Ohwi, Mem. Coll. Sci. Kyoto Imp. Univ., Ser. B, Biol., 18: 98 (1944); Koyama, J. Fac. Sci. Univ. Tokyo, Sect. 3, Bot., 7: 289 (1958).

A monotypic genus, extending from India to southern China and tropical Australia (Qld., N.T.). It is closely related to Schoenoplectus (q.v.).

1. H. grossa (L. f.) Nees, Edinburgh New Philos. J. 17 (34): 264 (1834).Scirpus grossus L.f., Suppl. Sp. Pl.: 104 (1781).--Schoenoplectus grossus (L.f.) Palla, Allg. Bot. Zeitschr. 17: Beibl. 3 (1911); Koyama in Hara et al., Enum. Fl. Pl. Nepal 1: 118 (1978).

Description: Kern (1974: 498).

Distribution: See above.

3. BOLBOSCHOENUS (Aschers.) Palla in Hallier, Synops. Deutsch. Schweiz. Fl. 3: 2531 (1905); Koyama in Hui-Lin Li et al., Fl. Taiwan 5: 206 (1979).Scirpus section Bolboschoenus Aschers., Fl. Brand. 1: 753 (1864); Koyama, J. Fac. Sci. Univ. Tokyo, Sect. 3, Bot., 7: 288 (1958).

Type species: B. maritimus (L.) Palla (Scirpus maritimus L.).

About 16 species widely distributed on all continents. This genus is close to Schoenoplectus (q.v.) and could be included in it if one took a broad view of generic limits (Lye 1971 b \& c), in which case Hymenochaeta should also be included. "Malacogeton" appears to be intermediate between Bolboschoenus and Schoenoplectus, being placed under the former by Koyama (1958) and under the latter by OtengYeboah $(1974$ b). Its embryo-type conforms better with that of Schoenoplectus than that of Bolboschoenus (Van der Veken 1965), which supports Oteng-Yeboah's placement of it as Schoenoplectus subgenus Malacogeton, based upon its culm anatomy and inflorescence and nut characters. 
Bolboschoenus has the most advanced embryo in the subfamily Cyperoideae, a highly differentiated form of the Schoenoplectus embryo-type. Leaf anatomy also suggests that the genus is derived from Schoenoplectus (Schuyler 1971 b). Morphologically, Bolboschoenus is distinctive with its noded culms and leafy involucral bracts; in the context of related genera it seems best to treat it as a genus. Specific limits are not clear and a worldwide study is needed.

\section{Key to Bolboschoenus species in Australia}

1. Nut trigonous, equilateral, with the dorsal angle acute; style 3-fid 2. B. fluviatilis

1.* Nut lenticular or trigonous with the dorsal angle obtuse; style 2-3-fid.

2. Style 2-fid; nut lenticular with concave sides, straw-coloured to deep goldenbrown, the surface \pm shining, minutely reticulate $\ldots \ldots \ldots \ldots \ldots \ldots$ 1. B. caldwellii

2.* Style 2-3-fid; nut plano-convex or trigonous with convex sides, red-brown to black, the surface shining, not obviously reticulate $\ldots \ldots \ldots \ldots \ldots, \ldots$, B. medianus

1. B. caldwellii (V. J. Cook) Soják, Cas. Nár. Mus., Odd. Přir. 141 : 62 (1972).Scirpus caldwellii V. J. Cook, Trans. \& Proc. Roy. Soc. New Zealand 76: 568, pl. 56, fig. 3 (1947).

Description: Moore \& Edgar (1970: 174).

Distribution: N.S.W., Vic., Tas., S.A., SW. W.A.; New Zealand.

2. B. fluviatilis (Torrey) Soják, Čas. Nár. Mus., Odd. Přir. 141: 62 (1972).Scirpus maritimus L. var. fluviatilis Torrey, Ann. Lyceum Nat. Hist. New York 3: 324 (1826). - Scirpus fluviatilis (Torrey) A. Gray, Manual Bot. N. United States: 527 (1848).

Description: Moore \& Edgar (1970: 173).

Distribution: SE. Qld. and coastal N.S.W.; New Zealand, Asia, North America.

3. B. medianus (V.J. Cook) Soják, Čas. Nár. Mus., Odd. Přir. 141: 63 (1972).-Scirpus medianus V. J. Cook, Trans. \& Proc. Roy. Soc. New Zealand 76: 569, pl. 56, fig. 2 (1947).

Description: Moore \& Edgar (1970: 174).

Distribution: N.S.W., Vic. Tas., S.A.; New Zealand, ? New Guinea.

4. SCHOENOPLECTUS Palla, Verh. K.K. Zool.-Bot. Ges. Wien 38, Sitzb.: 49 (1888); Bot. Jahrb. Syst. 10: 298 (1889); Koyama in Hui-Lin Li et al., Fl. Taiwan 5: 207 (1979); nom. cons.-Scirpus section Actaeogeton Reichb., Fl. German. Excurs.: 78 (1830); Koyama, J. Fac. Sci. Univ. Tokyo, Sect. 3, Bot., 7: 284 (1958).

Type species: S. lacustris (L.) Palla (Scirpus lacustris L.).

About 60 species, widely distributed on all continents. This is one of the largest Scirpus segregates and has been variously defined in the past to include, amongst others, Bolboschoenus and Isolepis (see Lye (1971 b) and Raynal (1976 a) for details of the nomenclatural history of the genus). The Schoenoplectus embryotype ('Scirpus' of Van der Veken) is considered to be the most advanced in the Cyperoideae, having evolved from a Cyperus-type embryo (which Isolepis possesses (Van der Veken 1965), indicating at least a distant relationship between Isolepis and Schoenoplectus). The relationship between Schoenoplectus, Bolboschoenus (q.v.) and Hymenochaeta (q.v.) is much closer. They share the same basic embryo-type but in varying stages of differentiation: Hymenochaeta has the least and Bolboschoenus the most differentiated. The gross morphology of these three taxa differs, as will be seen from the generic key, and, since this is correlated with the embryo variation, there seems sufficient reason to retain them as separate genera. 
TABLE 2

Recent infrageneric classifications of Schoenoplectus

\begin{tabular}{|c|c|c|c|c|}
\hline Koyama (1958) & Oteng-Yeboah (1974 b) & $\begin{array}{l}\text { Raynal (1976 a \& b } \\
1977 \text { a) }\end{array}$ & Type species & Australian species \\
\hline Scirpus sect. Actaeogeton & Schoenoplectus & Schoenoplectus & S. lacustris & \\
\hline series Actaeogeton & subgen. Actaeogeton & sect. Actaeogeton & S. mucronatus & S. mucronatus, S. pungens, ? S. lineolatus \\
\hline$"$ & $"$ & sect. Supini & S. supinus & $\begin{array}{l}\text { S. articulatus, } S . \text { dissachanthus, S. erectus, } S . \text { laevis, } \\
\text { S. lateriflorus, S. praelongatus }\end{array}$ \\
\hline series Lacustres & subgen. Schoenoplectus & (?sect.) Schoenoplectus & S. lacustris & S. validus \\
\hline series Litorales (as "Littorales") & ," & sect. Pterolepis & $S$. litoralis & S. litoralis \\
\hline $\begin{array}{l}\text { Scirpus sect. Bolboschoenus series } \\
\quad \text { Malacogeton }\end{array}$ & subgen. Malacogeton & $?$ & S. etuberculatus & - \\
\hline
\end{tabular}


Within Schoenoplectus various subdivisions have been proposed, notably by Koyama (1958), Oteng-Yeboah (1974 b) and Raynal (1976 a \& b). Their respective classifications are set out in Table 2. None of these is entirely satisfactory; for example, $S$. lineolatus does not fit well into any of the proposed groups. For this reason there seems no point in formally recognizing infrageneric divisions for the Australian species.

Raynal (1976 b) studied the occurrence of amphicarpy in Schoenoplectus and found that these unusual basal flowers occur only in species of sect. Supini. Not all species (nor, indeed, all individuals within a species) exhibit amphicarpy but the six species found in Australia do so.

\section{Key to Schoenoplectus species in Australia}

1. Inflorescence compound, with the lowest involucral bract usually shorter than or equalling the inflorescence; culms terete; nuts smooth.

2. Hypogynous bristles 5-6, setaceous, retrorsely scabrous; glumes distinctly ciliate

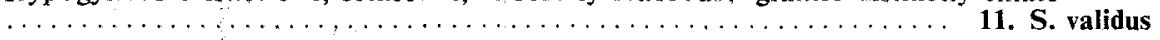

2.* Hypogynous bristles usually $4(3-5)$, flattened and spathulate, plumosely fringed with antrorse hairs; glumes only nicroscopically ciliolate . . . . . . . . . S. litoralis

1.* Inflorescence simple, capitate or with a few spikelets pedunculate; the lowest involucral bract much exceeding the inflorescence; nuts smooth or rugose,

3. Robust plants with culms (1-) 2-7 $\mathrm{mm}$ diameter.

4. Culms triquetrous, not septate; nuts smooth.

5. Glumes retuse, mucronate, with erose margins; leaf-blades present .

10. S. pungens

5. Glumes acute, mucronulate, margins not erose; leaf-blades absent .....

8. S. niucronatus

4. Culms terete, septate.

6. Nuts smooth

1. S. articulatus

6.* Nuts rugose

9. S. praelongatus

3.* Slender plants with culms less than or equalling $1 \mathrm{~mm}$ diameter, terete to subtrigonous.

7. Nuts smooth.

8. Glumes 1.7-2.2 $\mathrm{mm}$ long, obtuse; plants tufted

4. S. laevis

8.* Glumes $3.8-4.5 \mathrm{~mm}$ long, acute; plants at least shortly rhizomatous ... $\ldots \ldots \ldots$

7.* Nuts rugose.

9. Glumes yellow-tinged, glabrous; anthers 2; nut with acutely angled transverse ridges, dark brown and suborbicular, rarely black and obovate; hypogynous bristles present (rarely very short) $\ldots \ldots \ldots \ldots 2$. S. dissachanthus

9. Glumes red-tinged, ciliolate on margins; anthers 3; nut with broadly rounded transverse ridges, black, obovate; hypogynous bristles absent.

10. Style 3-fid; glumes $1.8-2.5 \mathrm{~mm}$ long

5. S. lateriflorus

10.* Style 2-fid; glumes 3-4 mm long

3. S. erectus

1. Sch. articulatus (L.) Palla, Bot. Jahrb. Syst. 10: 299 (1889); Raynal, Adansonia 16: 146 (1976).-Scirpus articulatus L., Sp. P1. 1: 47 (1753).

Distribution: Tropical Qld.; Africa, India, Ceylon.

This species has often been broadly defined to include $S$. praelongatus but it can be distinguished from the latter by its smooth nut, more narrowly ovate glumes and an involucral bract no more than twice as long as the distinctly septate culm (Kern 1974; Raynal 1976 b). 
2. Sch. dissanchanthus (S.T. Blake) J. Raynal, Adansonia 16: 139 (1976).Scirpus dissachanthus S. T. Blake, Victorian Naturalist 63: 116 (1946).

Description: Black (1978: 298).

Distribution: Inland regions of all mainland Australian States.

3. Sch. erectus (Poir.) Palla ex J. Raynal, Adansonia 16: 141 (1976).-Scirpus erectus Poir., Encycl. Méth., Bot. 6: 761 (1805).

Scirpus raynalii Schuyler, Notul. Nat. Acad. Nat. Sci. 438: 1 (1971).

Distribution: Scattered occurrences in *Qld., $+*$ N.S.W., *Vic.; Africa, Asia, North and South America.

This species has been confused with $S$. lateriflorus (e.g. Blake 1952) but they are distinct, as pointed out by Kern (1974). S. erectus has larger glumes, bifid style, larger biconvex nuts and a longer appendage on the anther connective.

4. Sch. laevis (S. T. Blake) J. Raynal, Adansonia 16: 151 (1976).-Scirpus laevis S. T. Blake, Proc. Roy. Soc. Queensland 51: 177 (1940).

Distribution: Inland regions of Qld., N.S.W., W.A. and N.T.

5. Sch. lateriflorus (Gmel.) Lye, Bot. Not. 124: 290 (1971).-Scirpus lateriflorus Gmel., Syst. Veg., edn 13, 1: 127 (1791).-Sch. supinus (L.) Palla ssp. lateriflorus (Gmel.) T. Koyama in Hara et al., Enum. Fl. Pl. Nepal 1: 119 (1978).

Description: Kern (1974: 514).

Distribution: Tropical Qld., N.T. and W.A.; South-east Asia.

$S$. erectus (q.v.) and this species have often been confused.

6. Sch. lineolatus (Franch. \& Sav.) T. Koyama in Hui-Lin Li et al., Fl. Taiwan 5: 215, Pl. 1322 (1979).-Scirpus lineolatus Franch. \& Sav., Enum. Pl. Japon. 2: 112 (1877), 544 (1879).

Scirpus forsythii Kükenth., Repert. Spec. Nov. Regni Veg. 12: 94 (1913), synon. nov.Holotype: Nepean River, W. Forsyth (B-not seen). Isotypes: MEL, NSW, P.

Description: Koyama (1979: 215).

Distribution: *N.S.W., *Vic.; Japan, Taiwan.

Schoenoplectus lineolatus is only known in Australia from three old and poorly documented specimens collected near Sydney and two very immature specimens from the Genoa River in the far north-east of Victoria. The stolons on these five specimens are not well-developed but otherwise there is agreement with the descriptions and specimens of $S$. lineolatus that I have seen from Japan. The sporadic occurrence in Australia suggests an introduced species.

7. Sch. litoralis (Schrad.) Palla, Bot. Jahrb. Syst. 10: 299 (1889).-Scirpus litoralis Schrad., Fl. Germ. 1: 142, t. 5, fig. 7 (1806).

Schoenoplectus subulatus (Vahl) Lye, Bot. Not. 124: 290 (1971).

Description: Kern (1974: 510).

Distribution: QId., N.S.W., N.T., S.A., W.A.; Mediterranean region to Africa and Asia. Very scattered in Australia and possibly introduced.

+ An asterisk before the name of a State or region implies that the species is introduced to that area. 
Specimens from Africa, India, Malesia, Micronesia and Australia have sometimes been distinguished as $S$. subulatus or $S$. litoralis ssp. thermalis (Trab.) Murb. in contrast to typical $S$. litoralis, which occurs in the Mediterranean region, S.W. Asia and China. Koyama (1958), Townsend (1962) and Kern (1974) agree that the only reliable distinguishing character between these two taxa is the culm shape: triquetrous in typical $S$. litoralis and terete (but trigonous just below the inflorescence) in $S$. subulatus. They disagree on whether this distinction is sufficient to warrant specific or even subspecific rank, and I have not yet seen sufficient material from regions other than Australia to form an opinion.

8. Sch. mucronatus (L.) Palla ex Kerner, Sched. Fl. Austr.-Hung. 5: 91 (1888). -Scirpus mucronatus L., Sp. P1., 1: 50 (1753).

Description: Kern (1974: 510).

Distribution: Qld., N.S.W., N.T., W.A.; Europe, Asia, Malesia, New Hebrides.

9. Sch. praelongatus (Poir.) J. Raynal, Adansonia 16: 148 (1976).-Scirpus praelongatus Poir., Encycl. Méth., Bot. 6: 764 (1805).

Description: Kern (1974: 513).

Distribution: Tropical Qld., N.T., W.A.; India to Vietnam, Malesia.

This species has often been considered a form of $S$. articulatus (q.v.).

10. Sch. pungens ( $\mathrm{Vahl}$ ) Palla, Bot. Jahrb. Syst. 10: 299 (1889)._Scirpus pungens Vahl, Enum. Pl. 2: 255 (1805); Schuyler, Rhodora 76: 51-52 (1974).

[Scirpus americanus auct. non Pers.]

Description: Black (1978: 296).

Distribution: N.S.W., Vic. Tas., S.A.; Europe, North and South America, New Zealand.

$S$. pungens has been widely known as $S$. americanus; the true $S$. americanus (Pers.) Volkart (Scirpus olneyi A. Gray) is found in North and Central America.

11. Sch. validus (Vahl) A. Löve \& D. Löve, Bull. Torrey Bot. Club 81: 33 (1954).-Scirpus validus Vahl, Enum. Pl. 2: 268 (1805); Blake, Trans. \& Proc. Roy. Soc. South Australia 67: 54 (1943). - Scirpus lacustris L. ssp. validus (Vahl) Koyama, Canad. J. Bot. 40: 927 (1962).

Description: Black (1978: 299).

Distribution: All Australian States except the Northern Territory; countries bordering the Pacific Ocean; New Caledonia, New Hebrides.

5. ISOLEPIS $R$. Br., Prodr.: 221 (1810); Raynal, Adansonia 17: 49 (1977).Scirpus section Isolepis (R. Br.) Griseb., Spicil. Fl. Rumel Bith. 2: 417 (1845); Koyama, J. Fac. Sci. Univ. Tokyo, Sect. 3, Bot., 7: 284 (1958).-Eleogiton Link, Hort. Berol. 1: 284 (1827).- -Scirpus section Eleogiton (Link) Reichb., Icon. Fl. German. 8: 38 (1846); Koyama 1.c.: 283.

Type species: I. setacea (L.) R. Br. (Scirpus setaceus L.)

About 70 species; widely distributed on all continents but with concentrations of species in eastern and southern Africa and Australia. 
Robert Brown (1810) defined the genus Isolepis by its lack of hypogynous bristles. This negative definition led to many unrelated species being placed there by nineteenth century botanists and consequently the genus was widely regarded as of no value. Isolepis is now generally recognised as a genus although generic limits have been variously set.

Van der Veken (1965) examined the embryos of 28 species in the EleogitonIsolepis-Scirpoides-Ficinia group and I have examined a further 22 species, including all Australian species of Isolepis as well as Isolepis spp. (Scirpus praetextatus Edgar and S. sulcatus Thouars) and Scirpoides sp. (Scirpus dioicus Boeck.). My results corroborate those of Van der Veken. The embryos of Ficinia, Isolepis and Eleogiton are extremely similar, with the root-cap in a cleft about halfway down the side of the embryo, the germination pore sublateral or nearly median, and the second leaf developed (all these characters as seen in profile (Van der Veken 1965)). Typically Scirpoides differs in having a superficial root-cap below the middle of the embryo, the germination pore median, and no second leaf developed. There are, of course, a few species that do not fit these stereotypes. Scirpus nodosus (traditionally placed in Scirpoides) has an embryo like that of Isolepis or Ficinia, while Scirpus humillimus and $S$. inundatus (both traditionally placed in Isolepis) have embryos which resemble more closely those of Scirpoides, and Scirpus hystrix (an Isolepis sp.) shows a mixture of characters from these two variants of the Cyperus-type embryo.

On the basis of morphological characters (such as the presence of a hypogynous disc on the nut in Ficinia), Isolepis and Ficinia (a southern African genus) are generally accepted as genera but the taxa Scirpoides (formerly Holoschoenus Link) and Eleogiton are less certainly placed (Raynal $1977 \mathrm{~b}$ ) and further study of generic limits is needed in these four taxa, particularly in southern Africa where all four occur.

Scirpoides Séguier seems a particular problem. S. holoschoenus (L.) Soják and allied species form a small but relatively well characterised European-African group of slender perennials with capitate, simple or compound inflorescences, readily distinguished from nearly all other species in this group of four taxa. However, the two species found in Australia that have been referred to Scirpoides, Scirpus nodosus and $S$. prolifer, both vary from typical Scirpoides, the former showing affinity with Ficinia and the latter with Isolepis. Because of the uncertainty of generic position for these two species, I have included them in Isolepis pending further investigation. Of the few records of rust or smut fungi attacking Isolepis spp., one species of rust fungus may be of interest here. Uredo scirpi-nodosi was described on Scirpus nodosus and has since been found on S. prolifer in Australia (John Walker, pers. comm.) and on S. inundatus and S. sulcatus in New Zealand (Cunningham 1924, 1927). This may indicate a relationship between the hosts as suggested by Savile (1972, 1979) for other Scirpus segregates but it would be premature to come to any conclusion on the basis of these four records of an imperfectly known rust.

There seems reason to regard Eleogiton as no more than an aquatic specialisation of Isolepis. Van der Veken found that Eleogiton embryos were very similar to those of Isolepis, differing only in being flattened. He attributed this difference (which he also found amongst Schoenoplectus and Fimbristylis spp.) to the digyny of Eleogiton species as opposed to the trigyny of the Isolepis species he examined. Lye \& Haines (1974) found several African species which could be regarded as morphologically intermediate between the long-stemmed, leafy, digynous, aquatic, perennial Eleogiton spp. with ebracteate, pedicellate, solitary spikelets and the small, terrestrial, often leafless and perennial, (2-) 3-gynous Isolepis spp. with 1-several sessile, pseudolateral spikelets with a leafy involucral bract. As mentioned under I. fluitans, even this, the type species of Eleogiton, shows considerable variation between aquatic and terrestrial forms, paralleling the seasonal variation observed by Levyns (1944) in the South African species I. rubicunda (Nees) Kunth. Because of this morphological variability, Eleogiton is not maintained here as a genus distinct from Isolepis. 
1. Style 2-fid.

\section{Key to Isolepis species in Australia}

2. Culms weak, floating or creeping, usually long and leafy; lowest involucral bract glume-like or with a short thickened appendage; spikelet one.

3. Spikelets ovate to broad-elliptic in outline, c. 15-flowered, $5-8 \mathrm{~mm}$ long; glumes $3.5-4 \mathrm{~mm}$ long; stamens $2-3$; anthers $1.0-1.5 \mathrm{~mm}$ long ..........

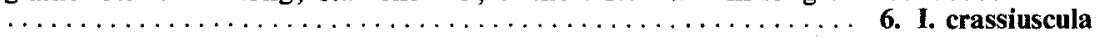

3.* Spikelets \pm elliptic, slender, 5-10 (-12) -flowered, 3-5 mm long.

4. Glumes c. $3 \mathrm{~mm}$ long, usually dark red-brown; stamens 3 ; anthers $1.5-2.7$ $\mathrm{mm}$ long; nut narrow-obovate in outline ............. 19. I. producta

4.* Glumes $1.8-2.7 \mathrm{~mm}$ long, occasionally with red-brown patches; stamens $2(-3)$; anthers $0.5-1.0 \mathrm{~mm}$ long; nut broad-obovate to broad-elliptic

8. I. fluitans

2.* Culms usually erect, often very short; lowest involucral bract leaf-like, usually as long as or exceeding the inflorescence; spikelets 1-15.

5. Dwarf plant with decumbent culms; involucral bracts several, at least twice as long as culms

11. I. humillima

5.* Erect plants to $35 \mathrm{~cm}$ tall; involucral bracts solitary, never more than half as long as culms and usually much shorter.

6. Glumes $1.5-2.1 \mathrm{~mm}$ long; nut $0.8-1.4 \mathrm{~mm}$ long.

7. Spikelets $3-15$ in an inflorescence.

8. Nut longitudinally striate and transversely trabeculate; stamens

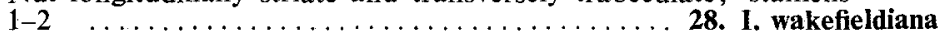

8.* Nut smooth; stamens $1(-2) \ldots \ldots \ldots \ldots \ldots \ldots \ldots$ 13. I. inundata

7.* Spikelets $1(-2)$.

9. Glumes red-brown with conspicuous fine, paler nerves; nut pusticulate $\ldots \ldots \ldots \ldots \ldots \ldots \ldots \ldots \ldots \ldots \ldots \ldots \ldots \ldots \ldots \ldots$ 23. I. setiformis

9.* Glumes green to straw-coloured with inconspicuous nerves; nut smooth

8. I. fluitans

6.* Glumes 2.3-3.5 mm long; nut 1.4-1.8 mm long.

10. Nut pusticulate, greyish; spikelet diameter $2.5-5 \mathrm{~mm}$.

11. Spikelet 1 ; involucral bract usually shorter than inflorescence and caducous; nut orbicular

17. I. oldfieldiana

11. Spikelets (1-) 2-5; involucral bract as long as or exceeding inflorescence and persistent; nut obovate to elliptic . . 7. I. cyperoides

10.* Nut smooth, yellowish; spikelet diameter 1.3-2.5 mm

8. I. fluitans

1.* Style 3-fid.

12. Plants with a long-creeping rhizome.

13. Slender perennial with numerous spikelets clustered in a dense globose

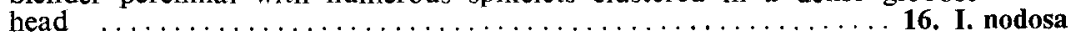

13.* Small annuals with 1-4 spikelets per inflorescence.

14. Stamens 3 (rarely $1-2$ in the upper flowers of a spikelet); spikelet $1(-2)$, partially enclosed in the enlarged base of the involucral bract; involucral bract caducous $\ldots \ldots \ldots \ldots \ldots \ldots \ldots \ldots, 2$. I. aucklandica

14.* Stamens 1-2 (occasionally 3 in lower flowers); base of involucral bract not enlarged; bract persistent.

15. Spikelet $1(-2)$; glumes $0.8-1.3 \mathrm{~mm}$ long, strongly keeled; nut stipitate but not abruptly so $\ldots \ldots \ldots \ldots \ldots \ldots 2$. I. subtilissima

15.* Spikelets (1-) 2-4; glumes 1.7-2.0 mm long, weakly keeled; nut abruptly stipitate $\ldots \ldots \ldots \ldots \ldots \ldots \ldots \ldots \ldots \ldots \ldots \ldots \ldots \ldots$ 26. I. tasmanica

12.* Plants tufted or with a short-ascending rhizome.

16. Spikelets squarrose; glumes with awns at least as long as the body of the

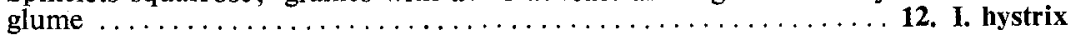

16.* Spikelets not squarrose; glumes not long-awned, occasionally shortmucronate. 
17. Nut longitudinally striate and transversely trabeculate.

18. Glumes 1.5-2.0 mm long; spikelets 3-15; stamen $1(-2)$; nut stramineous . . . .................. I. wakefieldiana

18.* Glumes 1.0-1.5 mm long; spikelets 1-2.

19. Nut \pm globose, dark grey-brown to \pm black; stamens (2-) 3 $\ldots \ldots \ldots \ldots \ldots \ldots \ldots \ldots \ldots \ldots \ldots$ 10. I. hookerana

19.* Nut obtusely and unequally trigonous, red-brown; stamens 2 $\ldots \ldots \ldots \ldots \ldots \ldots \ldots \ldots \ldots \ldots \ldots \ldots \ldots \ldots \ldots \ldots$ 22. I. setacea

17.* Nut smooth or minutely pusticulate.

20. Stamens 3.

21. Slender perennial with numerous spikelets clustered in a \pm dense head, usually proliferous $\ldots \ldots \ldots \ldots \ldots \ldots 20$. I. prolifera

21.* Small annuals with 1-4 spikelets per inflorescence, very rarely proliferous.

22. Glumes $2.5-3 \mathrm{~mm}$ long

1. I. alpina

22.* Glumes $0.8-2.2 \mathrm{~mm}$ long.

23. Nut $0.5-0.6 \mathrm{~mm}$ long.

24. Nut dark-brown to black; spikelets $1(-2)$; glumes $1.0-1.5 \mathrm{~mm}$ long ...... 18. I. platycarpa

24.* Nut straw-coloured; spikelets 1-3; glumes $0.8-1.2 \mathrm{~mm}$ long, usually with red-brown patches on the sides $\ldots \ldots \ldots \ldots, 3$. I. australiensis

23.* Nut $0.9-1.5 \mathrm{~mm}$ long.

25. Glumes obtuse

4. I. cernua

25.* Glumes acute.

26. Plant with leaves about twice as long as culms and involucral bracts as long as culms ............... 15. I. montivaga

26.* Plants with leaves and involucral bracts shorter than culms.

27. Nut unequally trigonous........ ................. 2. I, aucklandica

27.* Nut equally trigonous.

28. Plant short-rhizomatous; nut narrow-elliptic, pale yellow; glumes 1-2 mm long, thintextured, dull, with nerves not conspicuous ..... 9. I. habra

20.* Stamens 1-2.

28.* Plant tufted; nut narrowobovate, dark golden-brown; glumes $1.5-2.0 \mathrm{~mm}$ long, thick-textured, shining, with sides covered in conspicuous nerves

14. I. marginata

29. Nut $0.4-0.6 \mathrm{~mm}$ long.

30. Glumes $0.5-1.0 \mathrm{~mm}$ long, with 3-4 nerves spread over each side $\ldots \ldots \ldots \ldots \ldots \ldots \ldots \ldots \ldots \ldots \ldots \ldots \ldots$ 21. I. sepulcralis

30.* Glumes $0.8-2.0 \mathrm{~mm}$ long; sides markedly hyaline, with $0-1$ nerves on each side close to keel.

31. Hyaline sides of glumes $0.4-0.6 \mathrm{~mm}$ wide, with the cell outlines clearly visible at 15-20 times magnification (cells usually c. $0.1 \mathrm{~mm}$ long, $0.05 \mathrm{~mm}$ wide); glumes $1.5-2.0 \mathrm{~mm}$ long (rarely as short as $1.2 \mathrm{~mm}$ ); nut broad-elliptic to broadobovate, with the sides \pm concave, the margins acute, prominent; leaves of ten $4-9 \mathrm{~cm}$ long ..... $\ldots \ldots \ldots \ldots \ldots \ldots \ldots \ldots \ldots \ldots \ldots \ldots \ldots \ldots \ldots$ 5. I. congrua

31.* Hyaline sides of glumes $0.2-0.3(-0.4) \mathrm{mm}$ wide, with inconspicuous cells; glumes $0.8-1.6 \mathrm{~mm}$ long; nut obovate, with the sides convex or flat, the margins obtuse; leaves usually less than $3 \mathrm{~cm}$ long. 
32. Glumes usually with dark red-brown patches, $0.8-1.2 \mathrm{~mm}$ long, usually without a nerve close to the keel on each side; nut red-brown to dark red-brown .......... 3. I. australiensis

32.* Glumes usually pallid, rarely with red-brown patches, 1.1-1.6 $\mathrm{mm}$ long, with a nerve defining the keel margin on each side; nut grey to black at maturity ...... 27. 1. victoriensis

29.* Nut $0.7-1.5 \mathrm{~mm}$ long.

33. Plant with leaves twice as long as culms and involucral bracts as long as culms ............ 15. I. montivaga

33.* Plants with leaves and involucral bracts shorter than the culms.

34. Glumes with the broad keel produced in a stout mucro; spikelets usually 3 -numerous ....24. I. stellata

34.* Glumes mucronulate or with the obvious keel not produced at all.

35. Glumes with dark golden-brown patches; leaf-blades reduced; inflorescence never proliferating $. . . \ldots \ldots \ldots \ldots \ldots, 4 . \ldots$, 4. cernua

35* Glumes with dark red-brown patches.

36. Leaf-blades reduced, less than $1 \mathrm{~cm}$ long; spikelets $3-15 ;$ inflorescence usually proliferating ........ 13. I. inundata

36.* Leaf-blades $2-12 \mathrm{~cm}$ long; spikelets $1-3$; inflorescence occasionally proliferating $\ldots \ldots \ldots \ldots \ldots \ldots . . .$, I. habra (1947).

1. I. alpina Hook. f., Fl. Tasmaniae 2: 86, t. 143 (1860).

Scirpus gunnii Boeck., Linnaea 36: 493 (1870); Blake, Proc. Roy. Soc. Queensland 58: 39

Description: Willis (1970: 230).

Distribution: Alpine and subalpine regions of Vic. and Tas.

2. I. aucklandica Hook. f., Fl. Antarctica 1: 88 (1844), t. 50 (1845).-Scirpus aucklandicus (Hook. f.) Boeck., Linnaea 36: 491 (1870); Blake, Contr. Queensland Herb. 8: 18 (1969).

Description: Costin et al. (1970: 138).

Distribution: Tableland regions of southern Qld., N.S.W., Vic. and Tas.; New Guinea, New Zealand and associated subantarctic islands.

3. I. australiensis (Maiden \& Betche) K. L. Wilson, comb, nov.-Scirpus cernuus var. australiensis Maiden \& Betche, Proc. Linn. Soc. New South Wales 33: 316 (1908), basionym.-Holotype: Cobham Lake, N.S.W., W. Bäuerlen, 9.1887 (NSW 73353).-Scirpus australiensis (Maiden \& Betche) S. T. Blake, Proc. Roy. Soc. Queensland 51: 179 (1940).

Description: Black (1978: 297).

Distribution: Inland regions of N.S.W., Vic., ?S.A., N.T.; *New Zealand.

This species is very closely related to $I$. congrua and $I$. victoriensis. The three species can be distinguished by the characters given in the key; in addition, the culms have more clearly defined ridges in $I$. congrua and $I$. victoriensis than in $I$. australiensis, and the spikelets are generally larger in I. congrua than in the other species. The two New Zealand specimens I have seen (CHR 73796 and 92306) agree generally with I. australiensis, although the nut is more broadly obovate in the New Zealand specimens. 
4. I. cernua (Vahl) Roem. \& Schult., Syst. Veg. 2: 106 (1817).-Scirpus cernuus Vahl, Enum. Pl. 2: 245 (1805); Blake, Contr. Queensland Herb. 8: 18 (1969).

Scirpus psammophilus S. T. Blake, Proc. Roy. Soc. Queensland 51: 178 (1940).

Description: Black (1978: 297).

Distribution: Temperate and subtropical regions, mainly coastal, of all Australian States except the Northern Territory; nearly cosmopolitan.

This widespread and variable species, and allied species such as I. platycarpa, I. setiformis and $I$. verruculosa, need a world-wide study to determine specific limits. A 2-3-gynous form with blackish, broad-obovate nuts is widespread in Australia (also collected on Norfolk Island) and this may prove to be a distinct species.

5. I. congrua Nees in Lehm., Pl. Preiss. 2: 75 (1846).-Scirpus congrua (Nees) S. T. Blake, Proc. Roy. Soc. Queensland 48: 90 (1937).

Description: Black (1978: 297).

Distribution: Inland regions of N.S.W., Vic., N.T., S.A. and W.A.

This species is closely related to I. australiensis (q.v.) and I. victoriensis.

6. I. crassiuscula Hook. f., Fl. Tasmaniae 2: 86, t. 143, fig. A (1858).-Scirpus crassiusculus (Hook. f.) Benth., Fl. Austral. 7: 326 (1878).-Eleogiton crassiusculus (Hook. f.) Soják, Cas. Nár. Mus., Odd. Přir. 148: 193 (1979), as "crassiusculum".

Description: Costin et al. (1979: 138).

Distribution: Tableland regions of southern Qld., N.S.W., Vic. and Tas.; Japan, New Guinea, New Zealand.

7. I. cyperoides $R$. Br., Prodr.: 222 (1810).-Scirpus brunonianus S. T. Blake, Proc. Roy. Soc. Queensland 51: 179 (1940).

Distribution: SW. W.A.

8. I. fluitans (L.) $R$. Br., Prodr.: 221 (1810).-Scirpus fluitans L., Sp. Pl. 1: 48 (1753)._Eleogiton fluitans (L.) Link, Hort. Berol. 1: 285 (1827).

Isolepis lenticularis $\mathrm{R}$. Br., Prodr.: 222 (1810).

Description: Black (1978: 298).

Distribution: N.S.W., Vic., Tas., S.A., W.A.; Europe, Africa, Asia, Malesia, New Zealand.

The typical form of $I$. fluitans is aquatic, perennial, with long leafy culms and solitary pedicellate spikelets without a recognisable involucral bract. However this grades into a terrestrial state found on stream and pool margins, which resembles strictly terrestrial Isolepis spp. with tufted culms, a leaf-like involucral bract, and sessile spikelets. The very different appearance of this terrestrial state led Robert Brown to describe it as a new species, I. lenticularis, but there is no justification for this, since it grades into the typical I. fluitans form, sometimes within the one individual plant (Blake 1943; Black 1943).

9. I. habra (E. Edgar) Soják, Cas. Nár. Mus., Odd. Přir. 148: 194 (1979).Scirpus habrus E. Edgar, New Zealand J. Bot. 4: 199 (1966).

Description: Costin et al. (1979: 139).

Distribution: Widespread in the tablelands of N.S.W., Vic., Tas.; New Zealand, New Guinea, Philippines. 
As with other taxa occurring in both Australia and New Zealand, there appear to be differences between the populations of I. habra in the two countries. This species is very closely related to I. subtilissima, the distinctions between the two being most clear-cut in New Zealand. These two species need further study.

10. I. hookerana Boeck., Flora 41: 418 (1858), as "hookeriana".-Scirpus hookeranus (Boeck.) S. T. Blake, Contr. Queensland Herb. 8: 19 (1969).

Scirpus calocarpus S. T. Blake, Proc. Roy. Soc. Queensland 51: 179 (1940).

Scirpus setaceus auct. austr. non $\mathrm{L}$.

Description: Black (1978: 299).

Distribution: All Australian States except N.T.

11. I. humillima (Benth.) K. L. Wilson, comb. nov.-Scirpus humillimus Benth., Fl. Austral. 7: 324 (1878), basionym.-Holotype: South Alligator River, Arnhem Land, F. Mueller (K.) Probable isotypes: Tributary of the South Alligator River, Arnhem Land, F. Mueller 5.vii.1856 (MEL, 2 sheets).

[1. humillima Hochst. ex C. B. Clarke in Durand \& Schinz, Consp. Fl. Africa 5: 616 (1895), nom. nud. in synon.]

Distribution: Inland areas of northern Qld., N.T. and northern W.A.

This singular species is remarkable for its prostrate habit and capitate inflorescence, in which it is superficially similar to Cyperus pygmaeus. It differs from that species in glume and nut shape, in having spirally arranged glumes, and in having non-Kranz leaf anatomy. The embryo of this species resembles that of Scirpoides rather than Isolepis (see generic notes) but gross morphological features do not suggest a close relationship with Scirpoides or indeed any other genus. Pending further study of generic limits, this species is put in Isolepis.

12. I. hystrix (Thunb.) Nees, Linnaea 7: 496 (1832).--Scirpus hystrix Thunb., Prodr. Pl. Capensis: 17 (1794); Raynal, Adansonia 8: 98, pl. 1, fig. 13-15 (1968).

Description: Willis (1970: 228).

Distribution: Scattered occurrences in *N.S.W. and *Vic.; South Africa.

13. I. inundata $R$. Br., Prodr.: 222 (1810).-Scirpus inundatus (R. Br.) Poir., Encycl. Suppl. 5: 103 (1817). (1947).

I. gunnii Steud., Syn. Pl. Glum. 2: 94 (1855); Blake, Proc. Roy. Soc. Queensland 58: 40

Description: Black (1978: 299).

Distribution: All Australian States except N.T.; Malesia, New Zealand, Norfolk Island, Fiji, South America. This is a new record for Fiji, based on Latz NT 56894, collected "Nandi area, April 1971" and held in herb. NT.

This species is superficially similar to I. prolifera, and its embryo is more similar to those of Scirpoides spp. than to those of other Isolepis spp. (Van der Veken, 1965). As pointed out under the generic notes, these are two species which require further study to determine the most appropriate generic position. It is undesirable to make new combinations until such studies have been completed. 
14. I. marginata (Thunb.) A. Dietr., Sp. Pl., edn 6, 1 (2): 110 (1833); Raynal, Adansonia 14: 212 (1974).-Scirpus marginatus Thunb., Prodr. Pl. Capens.: 17 (1794).

I. cartilaginea R. Br., Prodr.: 222 (1810).

Scirpus antarcticus auct. non. L.: Blake, Contr. Queensland Herb. 8: 16 (1969).

Description: Black (1978: 296).

Distribution: N.S.W., Vic., Tas., S.A., W.A.; South Africa, New Zealand.

15. I. montivaga (S. T. Blake) K. L. Wilson, comb. nov.-Scirpus montivagus S. T. Blake, Proc. Roy. Soc. Queensland 60: 46 (1949), basionym--Holotype: Mt Buffalo, S. T. Blake 7375, 25.i.1935 (BRI). Isotypes: K, NSW.

Description: Costin et al. (1979: 139).

Distribution: Alpine and subalpine regions of southern N.S.W. and Vic.

16. I. nodosa (Rottb.) R. Br., Prodr.: 221 (1810).-Scirpus nodosus Rottb., Descr. Icon. Nov. P1.: 52, t. 8, fig. 3 (1773).-Holoschoenus nodosus (Rottb.) A. Dietr., Sp. Pl., edn 6, 2: 165 (1833).-Scirpoides nodosa (Rottb.) Soják, Čas. Nár. Mus., Odd. Přir. 141: 62 (1972), as "nodosus".

Description: Levyns (1950: 106).

Distribution: All Australian States except the Northern Territory, mainly coastal areas; widespread in temperate regions of the Southern Hemisphere (Skottsberg 1955).

This species may represent a link between Scirpoides and Ficinia. Superficially it resembles the former genus but it differs in having a small disc (which may or may not fall with the mature nut) at the base of the ovary (Levyns 1944) and also in embryo detail (Van der Veken 1965). It is interesting to note that most Flora writers have not mentioned the disc (gynophore), Bentham (1878) and Levyns (1950) being two exceptions. Owing to the uncertainty of generic placement of this species, I am leaving it in Isolepis pending further study of generic limits.

17. I. oldfieldiana (S. T. Blake) K. L. Wilson, comb. nov.-Scirpus oldfieldianus S. T. Blake, Proc. Roy. Soc. Queensland 51: 179 (1940), basionym.-Scirpus brizoides Benth., Fl. Austral. 7: 326 (1878), non Willd. ex Link (1820).-Part of the Holotype: Western Australia, 'without definite locality', Drummond 919 (BRI). Isotypes: MEL, NSW, P.

Distribution: SW. W.A.

18. I. platycarpa (S. T. Blake) Soják, Čas. Nár. Mus., Odd. Přir. 148: 194 (1979).-Scirpus platycarpus S. T. Blake, Proc. Roy. Soc. Queensland 51: 180 (1940).

Description: Black (1978: 301).

Distribution: N.S.W., Vic., Tas., S.A., SW. W.A.; New Zealand.

19. I. producta (C.B. Clarke) K. L. Wilson, comb. nov.-Scirpus productus C. B. Clarke, Bull. Misc. Inform. 8: 28 (1908), basionym.-Holotype: Tasmania, Gunn 1429 (K). Isotype: NSW.

Description: Black (1978: 301).

Distribution: South Coast of N.S.W., Vic., Tas., S.A., W.A.

This species is closely related to I. fluitans (q.v.), differing from the aquatic form of $I$. fluitans in its usually dark red-purple glumes c. $3 \mathrm{~mm}$ long (in fluitans: green or light red-brown and usually $2-2.5 \mathrm{~mm}$ long); 3 stamens with anthers $1.5-$ 
$2.7 \mathrm{~mm}$ long (fluitans. $2(-3)$ stamens with anthers $0.5-1.1 \mathrm{~mm}$ long); narrow-obovate nut with somewhat costate margins (fluitans: broad-obovate to suborbicular nut without costate margins); lowest glume bract-like and often as long as spikelet (fluitans: lowest glume not bract-like except in terrestrial state). Further study may show that these differences are not sufficiently constant to maintain I. producta as a species.

20. I. prolifera (Rottb.) R. Br., Prodr.: 223 (1810).--Scirpus prolifer Rottb., Descr. Icon. Nov, Pl: 55, t. 17, fig. 2 (1773).

Description: Moore \& Edgar (1970: 176).

Distribution: Scattered occurrences in *N.S.W., *Vic., *W.A.; South Africa, *New Zealand.

This species is superficially similar to Isolepis inundata (q.v.) but is generally coarser in habit. It may be better placed in Scirpoides or a genus of its own, but pending further study it is retained in Isolepis.

21. I. sepulcralis Steud., Syn. Pl. Glum. 2: 94 (1855); Raynal, Adansonia 17: 51 (1977). confus.

Scirpus chlorostachyus Levyns, J. South Afr. Bot. 10: 29 (1944); Raynal, ibid.: 51; nom.

Description: Moore \& Edgar (1970: 184).

Distribution: *Lower North and Central Coast regions of N.S.W.; eastern and southern Africa, Madagascar, *Tristan da Cunha, *St. Helena, *New Zealand.

22. I. setacea (L.) R. Br., Prodr.: 222 (1810).-Scirpus setaceus L., Sp. Pl. 1: 49 (1753).

Description: Clapham et al. (1962): 1068.

Distribution: *Tas.; Europe, Africa; introduced to many other regions.

23. I. setiformis (S.T. Blake) K. L. Wilson, comb. nov,-Scirpus setiformis S. T. Blake, Proc. Roy. Soc. Queensland 51: 178 (1940), basionym.-Holotype: Mount Barker, Oldfield (BRI). Isotypes: MEL, NSW.

Scirpus arenarius var. ? setiformis Benth., Fl. Austral. 7: 326 (1878).

Distribution: SW. W.A.

Blake explicitly describes this as a new species and does not base it on Bentham's variety. This species is closely related to 1 . cernua (q.v.) and African species such as I. verruculosa (Steud.) Nees.

24. I. stellata (C. B. Clarke) K. L. Wilson, comb. nov.-Scirpus stellatus C. B. Clarke, Bull. Misc. Inform. 8: 29 (1908), basionym.--Holotype: Victoria, F. Mueller (K). Isotype: MEL.

Description: Black (1978: 301).

Distribution: Central Coast of N.S.W. (?*), Vic., Tas., S.A., SW. W.A.

25. I. subtilissima Boeck., Flora 41 : 416 (1858).—Scirpus subtilissimus (Boeck.) S. T. Blake, Contr. Queensland Herb. 8: 20 (1969).

Scirpus merrillii (Palla) Kükenth. ex Merrill, Enum. Philipp. PI. 1: 117 (1923); Blake, Proc. Roy. Soc. Queensland 58: 38 (1947).

Description: Costin et al. (1979: 139).

Distribution: SE. Qld., coastal and tableland regions of N.S.W., Vic., Tas. and S.A.; New Zealand, Malesia.

This species is closely related to I. habra (q.v.). 
26. I. tasmanica (S.T. Blake) K. L. Wilson, comb. nov.-Scirpus tasmanicus S. T. Blake, Contr. Queensland Herb. 8: 21 (1969), basionym.-Holotype: Tasmania, between the Arthur River and Circular Head, F. Mueller (BRI 080376). Isotypes: $\mathrm{HO}$ (not seen), K, MEL.

Distribution: Tas.

27. I. victoriensis (N.A. Wakef.) K. L. Wilson, comb. nov.-Scirpus victoriensis N. A. Wakef., Victorian Naturalist 73: 163 (1957), basionym.-Holotype: Wimmera, Victoria, Reader 1891 (MEL). Isotypes: AD (not seen), BRI, K, NSW.

Description: Black (1978: 301).

Distribution: Inland regions of N.S.W. and Vic.

This species is closely related to I. australiensis (q.v.) and I. congrua.

28. I. wakefieldiana (S. T. Blake) $K$. L. Wilson, comb. nov.-Scirpus wakefieldianus S. T. Blake, Proc. Roy. Soc. Queensland 60: 45 (1949), basionym.Scirpus inundatus (R. Br.) Poir. var. pseudosetaceus Kükenth., Candollea 6: 427 (1936).-Holotype: Victoria, Healesville, Mt Blackspur, B. P. G. Hochreutiner 3017, 26.ii.1905 (B). Isotype: BRI.

Scirpus costatus (Hochst. ex A. Rich.) Boeck. var. $\beta$ gracilis Boeck., Linnaea 36: 511 (1870), synon. nov.-Lectotype (here designated): Tasmania, George Town, Gunn 420, 10.1.1843 (K).

Description: Willis (1970: 232).

Distribution: Vic., Tas.

The characters of this species seem to be intermediate between those of 1 . inundata and $I$. hookerana, and it may be of hybrid origin as suggested by Willis (1970). Its characters are similar to those of the African I. costata Hochst. ex A. Rich. but it seems preferable to maintain $I$. wakefieldiana as a separate species until further studies are made of all these species.

\section{OTHER SPECIES SOMETIMES INCLUDED IN SCIRPUS sens. lat.}

1. Lipocarpha microcephala $(R$. Br.) Kunth, Enum. PI. 2: 268 (1837).Hypaelyptum microcephalum R. Br., Prodr.: 220 (1810).

Rikliella australiensis J. Raynal, Adansonia 16: 220 (1976), synon. nov.

Scirpus squarrosus L. var. dietrichiae (Boeck.) Benth., Fl. Austral. 7: 329 (1878).

Description: Kern (1974: 522).

Distribution: All mainland Australian States; Malesia to Japan.

In Australia this species shows such unusual morphological variation in hyaline scale number and size, bract (glume) shape and mucro length that Raynal (1976) described a scaleless form as Rikliella australiensis. Since then a series of specimens with one or two reduced scales has been collected, connecting this with the typical $L$. microcephala with two hyaline scales enveloping the nut. This variation weakens the force of one of the main generic characters used to distinguish Lipocarpha, namely the presence of two hyaline scales at least as long as the nut and enveloping it. However, there is no reason to discard Lipocarpha as a genus: it is a generally coherent group of species, with this exceptional form in one species. As Raynal (1973) pointed out, it is not unusual to find these atypical forms and species amongst the more advanced genera of Cypereae, where the abundance of forms makes generic distinction difficult and gives the impression that "cette explosion évolutive est récente et n'a encore subi que peu d'extinction". 
2. Cyperus hamulosus $M$. Bieb., Fl. Taur.-Caucas. 1: 35 (1808).-Mariscus hamulosus (M. Bieb.) S. Hooper, Kew Bull. 26: 578 (1972).-Scirpus hamulosus (M. Bieb.) Steven, Mém. Soc. Imp. Naturalistes Moscou 5: 356 (1817).

This species from Central Asia and Africa is sporadically naturalised in inland Australia (S.A., N.T., the far NW. of Vic.), probably introduced with camels last century. It is included by Black (1978) under Scirpus but its affinities lie with Cyperus squarrosus L. (Mariscus squarrosus (L.) C. B. Clarke) (Raynal 1967). These two species belong to a highly evolved group within Mariscus sens. str. and should perhaps be treated at generic level as a specialised off-shoot of Mariscus. However, the delimitation of genera in tribe Cypereae is still under review and these two species are left in Cyperus sens. lat. pending completion of that study.

\section{ACKNOWLEDGEMENTS}

I am grateful for helpful comments on the manuscript received from various colleagues, especially Dr S. Jacobs, Dr L. Johnson and Mr D. McGillivray.

\section{REFERENCES}

Bentham, G. (1878). 'Flora Australiensis.' (Lovell Reeve \& Co.: London.) Vol. 7. Black, J. M. (1943). 'Flora of South Australia.' (Govt Printer: Adelaide.) Second edition, Pt. 1.

Black, J. M. (revised J. P. Jessop) (1978). 'Flora of South Australia.' (Govt Printer: Adelaide.) Third edition, Pt. 1.

Blake, S. T. (1943). Critical notes on the Gramineae and Cyperaceae of South Australia with descriptions of new species. Trans \& Proc. Roy. Soc. South Australia 67: 42-61.

Blake, S. T. (1952). The identification and distribution of some Cyperaceae and Gramineae, chiefly from Australia. Proc. Roy. Soc. Queensland 62: 83-100.

Brown, R. (1810). 'Prodromus Florae Novae Hollandiae.' (Taylor: London.)

Brown, W. V. (1975). Variations in anatomy, associations and origins of Kranz tissue. Amer. J. Bot. 62: 395-402.

Burbidge, N. T., \& Gray, M. (1970). 'Flora of the Australian Capital Territory.' (A.N.U. Press: Canberra.)

Carolin, R. C., Jacobs, S. W. L., \& Vesk, M. (1977). The ultrastructure of Kranz cells in the family Cyperaceae. Bot. Gaz. (Crawfordsville) 138: 413-419.

Clapham, A. R., Tutin, T. G., \& Warburg, E. F. (1962). 'Flora of the British Isles.' (Cambridge University Press: Cambridge.) Second edition.

Costin, A. B., Gray, M., Totterdell, C. J., \& Wimbush, D. J. (1979). 'Kosciusko Alpine Flora.' (CSIRO: Melbourne; William Collins: Sydney.)

Cunningham, G. H. (1924). The Uredinales, or rust-fungi, of New Zealand: Part 2. Trans. \& Proc. New Zealand Inst. 55: 13-58.

Cunningham, G. H. (1927). Fourth supplement to the Uredinales and Ustilaginales of New Zealand. Trans. \& Proc. New Zealand Inst. 57: 186.

Haines, R. W., \& Lye, K. A. (1971). Studies in Cyperaceae IV. Lipocarpha R. Br., Hemicarpha Nees, and Isolepis R. Br. Bot. Not. 124: 473-482.

Hitchcock, A. S., \& Green, M. L. (1929). 'International Botanical Congress Cambridge (England), 1930, Nomenclatural Proposals.' Pp. 111-199.

Kern, J. H. (1974). Cyperaceae (excluding Carex and Kobresia). In van Steenis, C. G. G. J. (Ed.), 'Flora Malesiana.' (Noordhoff: Leyden.) Vol. 7, pp. 435753.

Koyama, T. (1958). Taxonomic study of the genus Scirpus Linné. J. Fac. Sci. Univ. Tokyo, Sect. 3. Bot., 7: 271-366. 
Koyama, T. (1979). Cyperaceae. In Hui-Lin Li et al., 'Flora of Taiwan.' (Epoch Publ. Co.: Taipei.) Vol. 5, pp. 191-372.

Levyns, M. R. (1944). Notes on Scirpus and descriptions of three new species. J. S. African Bot. 10: 25-32.

Levyns, M. R. (1950). Cyperaceae. In Adamson, R. S., \& Salter, T. M. (Eds), 'Flora of the Cape Peninsula.' (Juta \& Co.: Cape Town \& Johannesburgh.) Pp. 97-132.

Lye, K. A. (1971a). Studies in African Cyperaceae II. The genus Oxycaryum Nees. Bot. Not. 124: 280-286.

Lye, K. A. (1971b). Studies in African Cyperaceae III. A new species of Schoenoplectus and some new combinations. Bot. Not. 124: 287-291.

Lye, K. A. (1971c). Moderne oppfatning av slekta Scirpus L. A modern concept of the genus Scirpus L. Blyttia 29: 141-147.

Lye, K. A., \& Haines, R. W. (1974). Studies in African Cyperaceae XIII. New taxa and combinations in Isolepis R. Br. Bot. Not. 127: 522-526.

Moore, L. B., \& Edgar, E. (1970). 'Flora of New Zealand.' (Govt Printer: Wellington.) Vol. 2.

Oteng-Yeboah, A. A. (1974a). Four new genera in Cyperaceae-Cyperoideae. Notes Roy. Bot. Gard. Edinburgh 33: 307-310.

Oteng-Yeboah, A. A. (1974b). Taxonomic studies in Cyperaceae-Cyperoideae. Notes Roy. Bot. Gard. Edinburgh 33: 311-316.

Raynal, J. (1967). Notes Cypérologiques: VI. Cyperus hamulosus M. Bieb. Adansonia 6: $581-588$.

Raynal, J. (1972). Répartition et évolution des modes de photosynthèse chez les Cypéracées. Compt. Rend. Hebd. Séances Acad. Sci., Ser. D, 275: 2231-2234.

Raynal, J. (1973). Notes Cypérologiques: 19. Contribution à la classification de la sous-famille des Cyperoidece. Adansonia 13: 145-171.

Raynal, J. (1976a). Notes Cypérologiques: 25. Le genre Schoenoplectus I. Sur quelques espèces sud-africaines. Adansonia 15: 537-542.

Raynal, J. (1976b). Notes Cypérologiques: 26. Le genre Schoenoplectus II. L'amphicarpie et la sect. Supini. Adansonia 16: 119-155.

Raynal, J. (1977a). Addendum to Notes Cypérologiques 26. Adansonia 16: 530.

Raynal, J. (1977b). Notes Cypérologiques: 32 . Le genre Isolepis R. Br. 1. Quelques espèces africaines. Adansonia 17: 49-57.

Savile, D. B. O. (1972). Some rusts of Scirpus and allied genera. Canad. J. Bot. 50: $2579-2596$.

Savile, D. B. O. (1979). Fungi as aids in higher plant classification. Bot. Rev. (Lancaster) 45: 377-503.

Schuyler, A. E. (1971a). Scanning electron microscopy of achene epidermis in species of Scirpus (Cyperaceae) and related genera. Proc. Acad. Nat. Sci. Philadelphia 123: 29-52.

Schuyler, A. E. (1971b). Some relationships in Scirpeae bearing on the delimitation of genera. Mitt. Bot. Staatssamml. München. 10: 577-585.

Skottsberg, C. (1955). On Scirpus nodosus Rottb. Acta Soc. Fauna Fl. Fenn. $72(20): 1-8, \mathrm{pl}$.

Townsend, C. C. (1962). A note on Scirpus subulatus Vahl. Kew Bull. 15: 415-417.

Van der Veken, P. (1965). Contribution a l'embryographic systématique des Cyperaceae-Cyperoideae. Bull. Jard. Bot. Etat 35: 285-354.

Willis, J. H. (1970). 'Handbook to Plants in Victoria.' (Melbourne University Press: Melbourne.) Second edition, Vol. 1. 